\title{
Security makes a difference: An Introduction ${ }^{1}$
}

\author{
Sigrid Ruby
}

Security and difference - the categories brought together in this volume are huge and multifaceted. We do not intend to define their meaning(s) narrowly - either in advance or in retrospect. We rather seek to explore their coexistence, relationship and interaction in particular historical settings, discourses and circumstances, taking into account different media and also visual culture. Our guiding assumption is that security makes a difference in multiple ways and is ambiguous in this capacity.

From an individual point of view and figuratively speaking, it makes quite a difference whether I am safe from physical or mental harm, whether I am securely sheltered and have a space for myself, whether I have access to food and education, whether I am healthy, have a partner, family and friends who care for me, whether I am free from oppression, discrimination and persecution. The question remains to what extent my personal safety needs and their satisfaction endanger the safety of others. This takes the issue of security to another level and concerns the social collective. Security turns out to be a limited resource that tends to be unequally distributed. Its management and distribution are the responsibility of the authorities, usually the government, whose position of power is often reified, legitimized and confirmed. A government must prioritize between more or less needy people, as well as between more or less pressing security issues. The desire for and guarantee of (whose?) security, obviously, are closely connected with differences that are constantly sought, asserted, reasoned and (re)affirmed. The priority given to one security issue will be at the expense of another; relative security of one social group might imply relative insecurity for another. Thus, authoritarian or state security policy is instrumental in creating and maintaining social differences, which in turn have their share in provoking and shaping collective security concerns. From a cultural-historical perspective, these have always

1 I am greatly indebted to Huub van Baar, Anja Krause, Angela Marciniak and Michael Quinn for substantive corrections, ideas, and suggestions for the writing of this introduction. Thanks are also due to Hans-Jürgen Bömelburg, Nicolas de Keyser and Karolina Kluczewska. 
been and still are highly dynamic and constantly overlapping processes with multiple variables. Their exploration demands a reconsideration of the conceptual assumptions and implicit challenges presented in Critical Security Studies as well as in postcolonialism.

In this volume, our interest is in specific historical situations wherein security and difference apparently interact or correlate. We want to ask to what extent securitization, i.e. declaring that something is a matter of security, operates on the basis of social differences and to what extent it produces and promotes them. In the following, I offer some basic considerations about difference and differentiation and their relevance to security issues. I begin by outlining a recent sociological approach, which is followed by a cursory review of concepts in cultural studies that address difference and intersectionality. This is done with consideration of both a postcolonial agenda and a historical perspective. Using the current COVID-19 pandemic and the political handling of it as an example, I demonstrate the complex interrelationship between security and difference and the social conditions that are revealed in it. The next section delineates the extent to which the (historical) interrelationship of security and difference has already been addressed in Critical Security Studies. It is apparent that the historical dimensions of this relationship have not yet been sufficiently studied. The fourteen chapters assembled in this volume make an important contribution to repairing this deficit. Their outline is reserved for the last section of this introduction.

\section{Difference and Differentiation}

Human lives all over the world, the realms of politics, economics, language, the arts, sciences and everyday practices ... - they all are based on differences and distinctions that give shape and structure to them, that enable analysis and decision-making. From a psychological-philosophical perspective, attempts at the rational ordering of the potentially chaotic phenomenal world that surrounds and affects us are constitutive of subject formation and concern everyone. In having formative (aesthetic, discursive, practical) access to the world, in making choices and, thus, differentiating, we experience ourselves as supposedly autonomous, self-determined and superior entities. We constantly - more or less consciously and deliberately - observe, mark, assert, construct, affirm, perform, criticize, insist on, ignore and flatten out differences when we deal with information, data, situations, people, consumer goods, political programs and the like. 
Beyond this very fundamental meaning of differences and differentiation as an everyday human practice and experience, there are social categories of difference that are scientifically studied and politically negotiated. Among the various ways to describe, categorize and deal with differences in the larger social fabric, ${ }^{2}$ particularly useful terminological and methodological foundations were laid by sociology. In "Un/doing Differences", the sociologists Stefan Hirschauer and Tobias Boll have recently defined "human differentiation" as a "cultural categorization of people" and, thus, emphasized its status as contingent and processual rather than natural (Hirschauer/Boll 2017). ${ }^{3}$ The authors discuss cultural categorizations and their respective logics that make individuals belong to a particular collective. Whereas ethnicity, religion and nationality tend to be more or less imagined affiliations, 'race', gender and age, for instance, rely to a large extent on the body as signifier and carrier of difference. Hirschauer and Boll point out that these categorizations also differ in their respective references and durations. 'Race', for example, is expected to remain a characteristic of a person throughout life, whereas national affiliation may change. While most sociologists prefer to understand these differences as properties of social organization, others, and also many political activists, tend to reify them as personal or collective identities. The situation is further complicated by the fact that people always fall within several categories at the same time, and that differentiations tend to intersect, overlap and coalesce. From a cultural studies perspective, the issue has been examined under the rubric of intersectionality, pointing to inequality effects when certain categories intersect (cf. Crenshaw 1989; Crenshaw 1991; Kerner 2009). According to Hirschauer and Boll, this often means that, for the sake of the argument, the wide range of difference categories is reduced too much (Hirschauer/Boll 2017, pp. 9-10).

"Un/doing Differences" explicitly proclaims a praxeological concept of "human differentiation". Thus, everybody's everyday performance is assumed to take part in the construction, affirmation and modification of difference(s). If an analytical perspective is to be grounded in this assumption, it must focus on the interactions and interdependencies of cultural categories of "human differentiation" and also explore their shift-

2 For a structured perspective on social and cultural difference(s), compare Kerner 2009. Kerner differentiates between the epistemic, institutional and personal dimension of difference(s).

3 In the original German it reads: „Thema dieses Bandes ist die kulturelle Kategorisierung von Menschen, die Humandifferenzierung." Hirschauer/Boll 2017, p. 7. My translation. 
ing rationales in terms of normative settings and ideology. What kind of (cultural, human) differences are constructed, articulated, represented, performed, institutionalized, legitimized as well as questioned, subverted, and criticized depends on who differentiates and from which social and political background, and how, when, where and for which reason(s). The historical perspective and the analytical methods of historicization are decisive to investigate these complex and ever-changing constellations adequately. For security research, the relevant question is whether differentiation and categorization can be perceived as practices or techniques of securitization.

Transculturalism, Deconstructivism, Postcolonialism. Conceptual Cornerstones and Potential Pitfalls of Analysing Difference in Historical Perspective

Not only in sociology, but also in cultural theory, difference remains a key concept that is ambivalently positioned within (de)constructivist agendas. In today's postcolonial thinking and practice, there exists a pronounced trend to challenge the idea of distinct identities and binary structures in favor of "queer", "inter", and, recently, "trans" - and all its extensions (transition, transfer, transversal, translation, transcendence, transgender, transsexual, transcultural, transdisciplinary, transmedial, transareal, transgression, etc.). Philosopher Paul B. Preciado expresses the hope that in the future "we will manage to overcome racial epistemology and sexual difference and to invent a new cognitive framework allowing the existence of life's diversity" (Preciado 2020, p. 42). He proposes "to think in terms of relation and potential for transformation, rather than in terms of identity" (idem, p. 41). The reflections of art historian Monica Juneja compete with Preciado's. As regards the postcolonial commitment to rethink the discipline and to conceptualize some sort of global or even planetary art history, Juneja suggests focusing on transcultural phenomena of encounters as they manifest themselves in discourses and material artifacts (Juneja 2017). Her rejection of cultural identity and multiculturalism as guiding categories of art historical analysis is reminiscent of the perspective taken by the literary scholar Mikhail Epstein. He considers "transculture a broad way between globalism and multiculturalism" and argues for difference as a "third category" that overcomes opposition and identity (Epstein 2009).

Preciado, Juneja and Epstein, who have been mentioned here as representatives of a much wider and highly diverse contemporary trend within and beyond academia, appear as heirs to a postcolonial agenda of differentiation and demarcation that they seek to overcome and take to 
a higher ethical level. Pointing out differences with regard to categories such as gender, 'race', sexual orientation and religion and with regard to their intersections has been and continues to be an important strategy for identity formation. It appears crucial for a consistent identity politics that denounces persistent inequalities and demands social justice, also in terms of security. Established hegemonic claims, Western white male supremacy in particular, are to be pushed back in favor of diversity and plurality to gain political recognition and representation. However, recent incidents, mainly in the academic and cultural sector ${ }^{4}$ have highlighted the problems inherent in any concept of personal and/or group identity. As Judith Butler (2004) has shown especially for the case of gender, identity norms force the individual who desires social recognition to submit or conform to these norms. Historical suppression and persistent systemic discrimination call for justice and emancipatory change. In that vein, a self-conscious identity politics on the part of the subalterns can be conceptualised as "strategic essentialism" (Spivak 2008) and, thus, considered a securitising move. Yet, restrictive essentializations or determinism are reintroduced when 'the Other' is represented and, thus, (re)racialized, as static and unalterable. Phenomena of "cancel culture" and "(reverse) racism" apparently go hand in hand with an identity politics that does not invite or allow one to go beyond one's (native) cultural identity.

Multiculturalism with its emphasis on pluralism and more or less stable cultural differences has a strong intellectual opponent in the deconstructivist philosophies of Jacques Derrida and Judith Butler in particular. Postmodern deconstruction recognizes the assertion of difference as the basis of all meaning. Mikhail Epstein points to

"this space of tension between multiculturalism and deconstruction $[\ldots]$ where the transcultural movement evolves. Transculture presumes the enduring 'physicality' and 'essentiality' of existing cultures and the possibility of their further transcendence, in particular through interference with other cultures. To be transcultural means to rise above one's inborn identity, such as 'adult white male', through the

4 For instance, there was a heated debate about the question, whether a white person can or should translate Amanda Gorman's poem The Hill We Climb, which the Black American author had recited at US President Joe Biden's inauguration in Washington, D.C., on January 20, 2021. Particularly in the British academic landscape, there have recently been controversial debates about allegedly transphobic statements made by feminist academics, such as Kathleen Stock of the University of Sussex. [https://www.pinknews.co.uk/2021/10/07/kathleen-stock-university-susse $\mathrm{x} /]$ 
variety of self-deconstructions, self-transformations, and interferences with other identities, such as a woman, a black, a child, a disabled person. For this purpose, books, films, and all works of art and culture are created and consumed: to dissolve the solidity of one's natural identity and to share the experience of 'the other'." (Epstein 2009, pp. 339-340)

This transculturalist paradigm has a visionary character but can nonetheless be useful for historical analyses. Its special appeal, but also its problem, lies in its genuine appreciation of differences which are conceived as the motor of social and cultural transformation. This progressivist narrative is reminiscent of cultural modernism and, thus, also brings to mind historical biases and pitfalls.

To "make a difference" from a transculturalist perspective can mean that someone or some entity recognizes and accepts someone else as (somehow) different. That they have an interest in and want to get to know 'the Other' in order to expand their own horizon, to transform themselves and their behavior, including political and administrative action. Leaning in and positively relating to what is acknowledged as different may end up in hybridity or de-differentiation and opacity, at least temporarily, but does not mean giving up the recognition of difference in principle (cf. Glissant 1990; Julien 2016). To acknowledge someone or something else as different - or 'Other' - may also inspire reflection of one's situated subjectivity as well as of one's objectifying, colonizing, subordinating, submitting, adoring, desiring or just interested gaze. Along these lines, art historian Viktoria Schmidt-Linsenhoff (2010) talks about a "postcolonial aesthetics of difference" that make us not only tolerate 'Otherness', but also self-consciously enjoy it as a personal connection to the world at large.

Nonetheless, whenever there is power imbalance and/or lack of mutual interest, the danger of overly friendly embraces and encroaching appropriations of 'the Other' - rather than acceptance of difference as a value in and of itself - is imminent. Historically, to explore and expand the self via seeking and sometimes even merging with 'the Other' has been a key issue, for example, in European Romanticism and artistic modernity. ${ }^{5}$ Interest in 'the Other' often partook in colonial adventure and exploitation, which

5 The poet Arthur Rimbaud took a completely different approach. His well-known dictum of 1871 - "Car Je est un autre" ("For I is another") - speaks to the importance of difference within and persists as a rallying point for all those who question the existence of stable identities and, as a consequence, either rejoice in the dynamics of personal diversity or suffer from inner conflict and mental instability. Cf. 
fueled modern fantasies of the necessarily passive 'Other' as pure, original, simple, exotic and in need for civilizing mission. In Orientalism, cultural critic Edward Said (1978) analyzes this historical perspective of subjugation and concomitant aesthetic practices of European imperial dominance. The colonizing gaze and image production determine 'the Other' a spectacle of difference. 'The Other' gets racialized by being presented as static and unalterable, its supposed subalternity thus being naturalized, essentialized and/or mythologized.

Both orientalization/exoticization and appropriation are practices characteristic of a colonial situation, wherein "making a difference" is a prerequisite for more or less unabashedly exercising power over people, objects and spaces. However, as key cases of (racial) historicism exemplify, powerful colonial regimes can also be based on the enactment of gradual rather than essential difference and operate with a narrative of progressive civilization. Some of the colonized populations were qualified as 'improvable' when being guided by the colonizers. Even today, countries are referred to as "developing countries", which implies that they could develop towards the position of developed ones if they managed to become incorporated in globalized capitalist economies. Thus, historically as well as systematically, one has to distinguish, as Theo D. Goldberg (2002) proposes, between the racialization of 'the Other' via (aesthetic) naturalism/essentialism and the racialization of 'the Other' via (historical) narrative/historicization. The selection and examination of source material has to take this into account. We also have to critically reflect on the paradigms and Eurocentric biases of our academic discipline(s) in order to analyze adequately the formative power of media and narration - and of their interactions (cf. Hobson 2010).

\section{Security and Difference. The example of the COVID-19 pandemic}

As we argue in this volume and seek to explore further, difference and differentiation are contingent on or at least central to (in)security and, thus, also to Critical Security Studies including securitization theories. Differences are made out and articulated when- and wherever (in)security becomes a collective issue in need of authoritative treatment. A brief look

Rimbaud, Arthur: Lettres du voyant (13 et 15 mai 1871), edited and commented by Gérald Schaeffer, Geneva/Paris 1975, pp. 134-144, here p. 135. 
at what happened at the beginning of the COVID-19 pandemic can give us some initial insight.

Physicians and virologists have been and still are doing research and try to understand the coronavirus, which is invisible to the naked eye, but obviously dangerous to the human body, mind and psyche. When the pandemic emerged at the beginning of 2020, at least three ways to deal with it bio-politically were dominant, also in combination and involving different temporal levels of response. ${ }^{6}$ Firstly, people could endure the virus collectively and make it part of their physical bodies and lives. Thus, by focusing on the possibility of group immunity, so the argument went, we could eventually defeat COVID-19. As we know today, this solution would have cost many, many lives worldwide. Secondly, infected people could - first - be isolated to stop the virus's spreading and - then - be treated with drugs and other therapies to alleviate COVID-19's physical damage. Thirdly, a vaccine could be developed that would make people immune to the virus and, thus, protect them and others against it. Knowing of, but not knowing enough about COVID-19 to be able to take effective action in the short term has become a tricky security problem, to which many national governments attach great political importance. The particular challenge results from the fact that it is not clear what kind of temporal and spatial solution is best to manage the threatening situation. Additionally, there is the ongoing problem of who is authorized to be(come) a security expert, and who is authorized to communicate the alleged crisis and its eventual solution. Future research will certainly focus on how exactly this crisis came about and what kinds of dynamics were involved, when political leaders and governments all over the world had to react to a situation that was - and still is - extraordinarily pressing and confusing. However, as regards making and dealing with differences in Corona times, one could already record some observations here: Ongoing scientific research into the virus and its effects on the human organism has revealed differences that relate to sex, age, ethnic and social background, lifestyle, living conditions, profession, state of health, body weight etc. of the person infected. Accordingly, security measures were taken and legitimized, which in fact securitized groups of people by classifying them as either dangerous, that is contagious, or endangered, that is particularly vulnerable. This happened, for example, to loan workers, most of them EU

6 These bio-political options are laid out here rather crudely and certainly need a more thorough analysis, especially in the wake of Michel Foucault's (2008) seminal examination of bio-politics as a technology of power. 
citizens from Central and Eastern Europe, in the German agriculture and meat industry, ${ }^{7}$ as well as to old and disabled people in nursing homes. Both social groups got more or less isolated from the rest of society in order to prevent the virus's "super-spreading". While the fate of these two groups received a lot of media attention, their actual scope of action and perception was drastically reduced. This is just one of many cases in which securitization and increased public media visibility go hand in hand, and where the threat of danger is embodied in the flesh.

Whereas COVID-19 may legitimate political authorities to differentiate, the course of the pandemic also made it clear that there are pronounced social differences in access to collective resources and thus also to protection and treatment in case of infection, disease and disability. In the United States, for instance, a racialized (and nationalized) distribution of life chances became obvious once again. Prioritizing medical assistance may be forbidden, but so-called "triage", i.e. the distinction between lives that are more or less worth preserving, becomes a reality when the infrastructure collapses and/or the ratio of nation-state social security systems takes hold.

Closing and controlling national, federal and district borders has become a key security measure to contain the virus and the population. Via the hashtag \#stayathome people were requested to stay off the traditional public sphere, which in turn got relegated to virtual spaces and online platforms. At times of mandatory self-isolation, physical contact with anyone other became an ambivalent privilege as well as an obligation reserved for "key workers", that is groups and individuals considered relevant for basic social operations ("systemrelevant" in German). While fighting the virus was becoming almost routine, who or what was collectively important next to this key objective required prioritizing and, thus, making differences in allocating political attention and public money. In case the economy had to be prioritized, then what kinds of branches had to be dealt with first? If education and childcare, then what age groups should be

7 Huub van Baar on the issue in a 2021 conversation with me: "When Europe was under severe lockdown in the spring of 2020 and air traffic heavily reduced, 188 flights with seasonable workers - many of them with private jets arranged by labor offices in Germany, the UK, France, Belgium and the Netherlands - were nevertheless flying from mostly Romania to these Western EU member states. Several of these workers got infected during work in agriculture and in meat factories. These flights were possible due to an EU regulation making an exception to the general lockdown rules, for so-called ,critical workers', that is those necessary in the relevant industries for the maintenance of ,our' consumption. I would say that this is a clear European equivalent of the American racialized (and nationalized) distribution that you discuss here." 
selected firstly? If mobility, then whereto and with what kinds of vehicles? If science, then what faculties and disciplines should be prioritized? If culture, then high or low, public or private?

It has become increasingly apparent that the coronavirus is not the cause, but rather an occasion for the manifestation of numerous security problems worldwide that are essentially related to social differences and their cultural imprint. Governments and local authorities, particularly in rich and democratic Western nations, are trapped in properly balancing public health requirements on the one hand, and safeguarding societal prosperity on the other. These two policy fields compete and intersect, while their treatment might also appear subordinate to a much larger security problem of global or even planetary proportions, which is related to man-made climate change. Neither the COVID-19-pandemic nor the climate change follow 'man-made' rules, but social factors. Consequently, categories of difference have huge influence on the severity with which people are affected. Inevitably, both these 'crises' respond to and interact with differences humans have created and continue to "un/do" all over the world.

\section{Security and Difference in Critical Security Studies}

The co-constitution of security and difference has been a basic premise of Critical Security Studies. One of the conceptual parameters of the Copenhagen School as it developed in the 1990s is a sectorial approach. Copenhagen distinguishes between larger and smaller social entities, and its analytical focus is on the large-scale social collective exclusively. In this approach, societal security, most often meaning the security of a nation state, takes precedence over the interests and needs of smaller social groups and individuals (cf. Wæver 1993; Buzan/Wæver/de Wilde 1998). Barry Buzan and Ole Waever, who are often considered the Copenhagen School's main representatives, have argued that, in order to defend societal security, modern states can slip into securitization ("Versicherheitlichung" in German) and, thus, move away from what they understand as 'normal politics.' Securitization here means that topics are transformed from regular political issues into matters of security by state authorities or influential social-political actors. Buzan and Wæver use John L. Austin's speech act theory to analyze securitizing moves and related crisis narratives that enable and legitimate extraordinary measures potentially at odds with 'normal politics.' As Lene Hansen, another prominent representative of the Copenhagen School, has succinctly pointed out, there exists what she calls a "silent security dilemma" (Hansen 2000). Some people, she 
argues, cannot voice or otherwise articulate their situation of insecurity, because doing so could or would endanger their societal situation even more. The merit of Hansen's critical take on the Copenhagen School's original theorization has been multiple. First, she has demonstrated that majority cultures and the affordances of 'normality' silence certain members of social collectives. Secondly, she revealed that there is a conspicuous absence of dealing with gender in the Copenhagen School. And finally, she has clarified that "not speaking", not articulating one's insecurity can, paradoxically, also be a political strategy to protect oneself or to achieve relative security for the ones who are not in power or endangered by those in power. Her critical intervention made one think of Gayatri C. Spivak's seminal essay "Can the subaltern speak?" (1983). In turn, Spivak's essay inspired Sarah Bertrand to contribute to the debate with her essay "Can the subaltern securitize?" (2018), in which she systematically analyzes, albeit not in historical depth, whether and why the subaltern can(not) speak, is (not) listened to, or is (not) understood. Bertrand comes to the conclusion that - due to the conceptual presuppositions of the Copenhagen School approach - the subaltern will under no circumstances be able to securitize.

Within Critical Security Studies, the so-called Paris School ${ }^{8}$ has also problematized the reliance on discursive enactments and on a normative notion of 'normal politics.' Representatives of this strand of research are not only interested in exceptional situations or extraordinary constellations, but also in everyday processes and practices of (in)securitization as well as in the local material, empirical arrangement and negotiation of security (e.g., Bigo 2002; Bigo/McCluskey 2018; Huysmans 2006; Huysmans/Dobson/Prokhovnik 2006). In this analytical context, differentiations along the key categories of intersectionality play a significant role. Yet, intersectional specificities often remain underrepresented in the work of the Paris School, while a historical and historicizing perspective is also mostly absent. Furthermore, though difference is often recognized as key to practices of (in)security, the agency of those who are differentiated through (in)securitization still needs to be articulated much more prominently than has hitherto been done in Critical Security Studies in general.

A fresh perspective on the historical relationships between security and difference has recently been brought forward by a provocatively formulated critique of Critical Security Studies and its Copenhagen branch in particular.

8 As regards the difference between a "Paris" and a "PARIS" approach to securitization see Bigo/McClusky 2018. 
Alison Howell and Melanie Richter-Montpetit $(2020)^{9}$ argue that for authors such as Barry Buzan and Ole Wæver it is, as a matter of course, the liberal democracies of Western character that they mean as representing 'normal politics.' Howell and Richter-Montpetit argue that the whole concept of normal politics introduced by Buzan and Waever is fundamentally biased and, as such, has its historical roots in the European Enlightenment. According to them, "Copenhagen School securitization theory is structured not only by Eurocentrism but also by civilizationism, methodological whiteness, and antiblack racism." (Howell/Richter-Montpetit 2020, p. 3; see also Howell/Richter-Montpetit 2019) What the representatives of the Copenhagen School designate as 'normal politics', Howell and Richter-Montpetit argue, is grounded in a tradition of racism and white supremacy. These, the critiques say, get protected from 'extraordinary' disturbances by way of securitization.

"Securitization theory's racism is [...] evident in its methodology, which examines securitizing speech acts in order to defend this (European, civilized) 'normal politics'. Under cover of ostensibly neutral terms, securitization normatively prioritizes the defense of order over justice, positioning the securitization theorist as the defender of (white) civilized politics against (racialized) 'primal anarchy.'" (Howell/Richter-Montpetit 2020, p. 16)

This is not the place to deal with the ramifications of Critical Security Studies in greater detail. However, not the least in the light of Howell and Richter-Montpetit's historically argued critique, it seems to be very clear by now that the structural violence of established norms - or 'normality' (most often through male, white, hetero etc. perpetuators) - requires substantially more analytical and empirical attention in Critical Security Studies. Its traditions and historical specificities do not seem to have been sufficiently recognized as enabling and preforming (in)securitization and, moreover, as constituting a series of security problems of their own kind. Security risks are usually identified with those groups who are considered a potential threat to social and political normality (e.g., communists, feminists, people of color, LGBTQI+ people, migrants, Muslims, Jews, Roma, 'Others' in general), while their own security needs receive relatively minor attention. Mentally deep-seated and routinely practiced sexism and racism generate a normative social identity that becomes a referent object for security and

9 See also the responses to Howell and Richter-Montpetit: Hansen 2020; Wæver/Buzan 2020. 
prompts (in)securitization. Or, to put it another way, established security concepts and the logics of (in)securitization tend to operate with, reinforce and (re)construct socio-cultural differences in terms of 'race', ethnicity, class, sex, gender, age and the like and, oftentimes, stabilize a dominant majority culture, whose power is to a considerable extent based on sexism, racism and their intersections.

Despite the fact that some of Alison Howell and Melanie Richter-Montpetit's remarks are rather provocative and polemical, their critique has further encouraged and empowered a cultural-historical perspective on the nexus of security, difference and intersectionality. A historically informed approach is necessary in order to get a broader picture for discussing social rather than societal - security as well as their often-contradictory interplay.

\section{On this Volume}

While sociology and (postcolonial) cultural theory have delineated ways to conceptualize difference, intersectionality and identity in order to analyze differentiation processes and practices of recognition, discrimination and "un/doing difference", a critical perspective on the sources is a special competence of the historical sciences. As Lene Hansen and others have pointed out, one problem in Critical Security Studies is that of a source selection that in itself tends to be biased. When research relies more or less exclusively on speech acts, it runs the risk of neglecting forms and media of articulation different from language. Furthermore, languagebased discourse neither was nor is it now available to everybody, and not every speech act was or is considered worth hearing or recording. A source critical research starts from here and makes historical remnants (writing, images, imprints, objects, sounds, spaces, practices, etc.) as well as archival voids speak for themselves, thereby enriching and diversifying our perception of historical security concerns. A critical and at the same time productive perspective on (in)security tries to uncover the blurred traces of the subalterns' capacity for action and subjectivity and, for that matter, also study exactly those images, writings, etc. that rendered them invisible and mute (Schmidt-Linsenhoff 2010, p. 18). As, in the context of feminism, Gayatri C. Spivak pointedly states:

"A very general definition of work for feminism is to research how humankind is not nice to women and queers in different ways, and to see how this operates a structure of approved violence at one end and 
alibis for the interventionist missionary impulse at the other." (Spivak 2012, p. 123)

The fourteen contributions assembled in this volume are case studies that focus on historical differentiation processes along the lines of, most notably, class, gender, 'race', ethnicity and religion as they were implemented and practiced with direct or indirect reference to (in)security. The way in which the chapters are ordered in this book does not follow a chronological or disciplinary order, but reflects systematic issues that arose from our shared research concerns.

The first part, Communities, deals with the negotiation of security interests between the authorities and different social groups within a spatially and temporally defined community. Stefanie Rüther looks at the city of Nuremberg in the late $14^{\text {th }}$ century and analyzes "pragmatic differentiation" as a means of regulating relative (in)security within the framework of the polity in a moment of crisis. The physical inspection of the city's inhabitants played an essential role in the decision-making process. The state of the body, its relative fitness for collectively important tasks as well as its social marking also play an important role in Florian Neiske's contribution. His analysis of a historical crisis situation in the Indian seaport Calcutta in 1864 reveals contradictions within the ruling ideologies of British colonial policy that come to light when conceptions of security and categorizations of difference collide. Whereas the seamen in Calcutta got public visibility but hardly any voice, speaking up for their social rights and own security interests was an important strategy for Black people in colonial Brazil, as demonstrated by Jorun Poettering. Her chapter on the situation in Brazil in the $19^{\text {th }}$ century shows that silence can consolidate social discrimination and hinder equal access to security. Christine Krüger's contribution is a comparative analysis of large-scale settlement projects and phenomena of house-squatting in the 1970s in Hamburg and London respectively. She asks how group identities are constructed and hierarchized via the perception of people as either 'endangered' or 'dangerous', as either 'in need of protection' or 'entrusted with the task of protection'.

A second group of papers focusses on Representations as a major vehicle of "human differentiation" (Hirschauer/Boll 2017) and securitization. Using the example of Hungarian cartoons in popular magazines from 1890 to 1914 , Peter Haslinger demonstrates the power of imagery and ridicule to present minorities as "dangerous others". He examines the part these cartoons played in a politics of difference that characterized the multiethnic state of Hungary around 1900. A minority that has traditionally been stigmatized as a "dangerous other" by majority European cultures are 
the Sinti and Roma. In her contribution Laura Soréna Tittel analyzes the criminalization of 'Gypsies' in different visual media and contexts from the late $18^{\text {th }}$ to the $20^{\text {th }}$ century. Julia Wurr, in turn, examines Neo-Orientalist representations of the Islamic Other. Her exemplary starting point is the BBC film series Bodyguard (2018), in the analysis of which Wurr shows the making and effectiveness of a racialized "poetics of insecurity".

If and how a "poetics of insecurity" is at work, remains a crucial question for historical research. The representation or evocation of insecurity is an artistic device that mostly enhances the entertainment value of an image or story. ${ }^{10}$

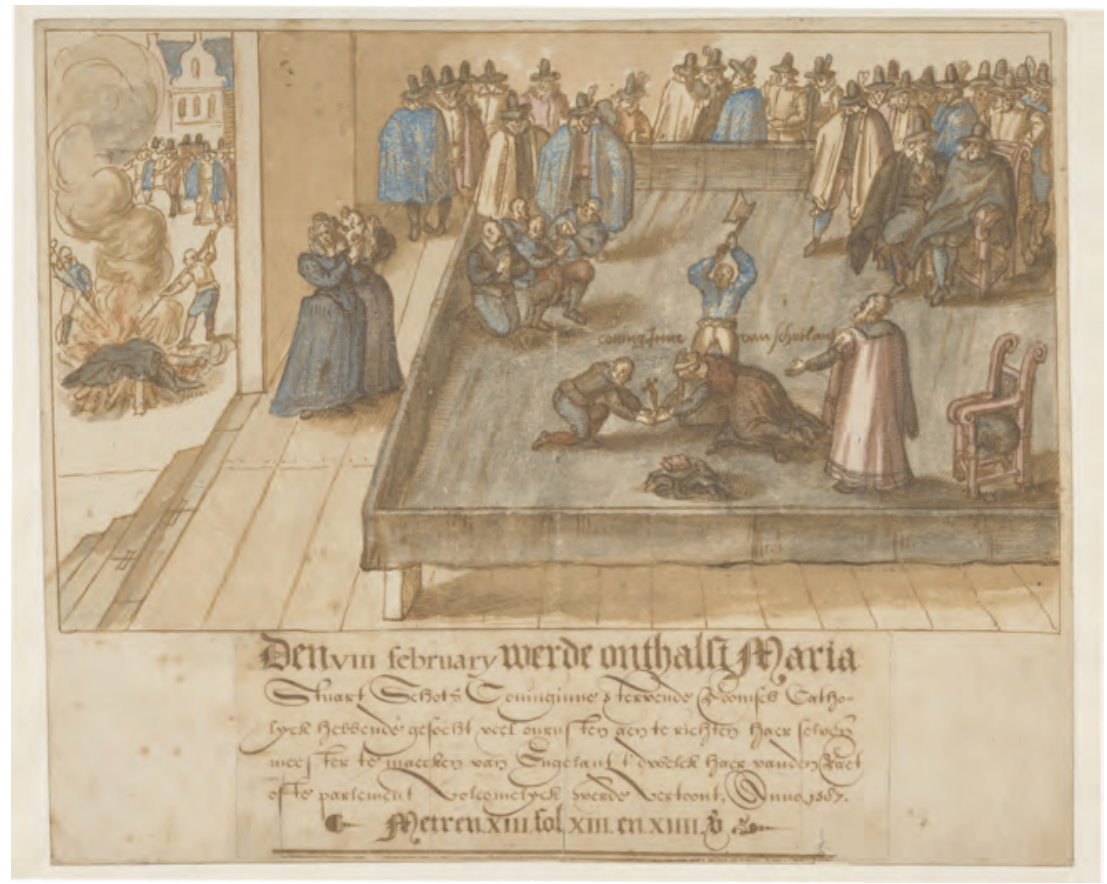

Fig. 1: anonymous (Dutch), The Execution of Mary, Queen of Scots, 1542 1587, about 1613, watercolor on paper, $21.90 \times 26.40 \mathrm{~cm}$, Edinburgh National Galleries of Scotland, Purchased 1934

10 See also Voelz 2017. 
The Early Modern watercolor showing the execution of the Queen of Scots in 1587 (fig. 1) demonstrates how images work to dramatize and heighten the meaning of historical events, which are thus (re)remembered as tipping points of (in)security. The annotated image, that we chose for this volume's cover, was made for a Dutch magistrate who compiled an album of historical prints and drawings in $1613 .{ }^{11}$ It shows on the right a scene with many figures, arranged on an indoor scaffold, in the center of which the executioner stands ready to behead the Scottish queen kneeling right before him. On the left, the stage opens to a view of a Dutch-like city, where a large fire is lit to burn Mary's clothes.

As Anja Krause demonstrates in her contribution, the execution of Mary, Queen of Scots, was an important step taken by Queen Elizabeth I in securing the Tudor monarchy. Krause analyzes the security discourses kindled by the threatening 'differences' of women rulers and the discriminating notions of royalty that they imply. Her investigation of Early Modern female rulership kicks off the third part of this volume, which deals with Power, Jurisdiction and Bureaucracy. Gabriele Hackl analyzes how the German National Socialist regime systematically produced insecurity in order to impose new procedures, legal norms and case law. Her source material consists of legal cases heard by the so-called "Special Court" in Vienna. Hackl demonstrates how difference and deviancy were constructed via securitization whose referent object was a supposedly homogeneous national community ("Volksgemeinschaft"). Controlling and categorizing the more or less destitute segments of the population as part of a security policy is also explored by Sigrid Wadauer. She examines a representative sample of employment record books ("Arbeitsbücher", "Dienstbotenbücher") that were widely used in the Habsburg Empire in the $19^{\text {th }}$ and early $20^{\text {th }}$ centuries. Whereas public authorities and employers perceived these books as an indispensable prerequisite for maintaining security and order, they also offered chances for cheating or misuse depending on their owners' needs for either protection or personal freedom. Marcel Schmeer's contribution deals with the history of the police as a "differentiating apparatus" within modern state power. His analytical focus is on the police in West Berlin in the 1970s, whose internal relations, based on gender and other differences, are examined as well as their interaction with the public, whom the police must protect but also consider potentially delinquent. Schmeer demonstrates how relationships of difference went along with conceptions

11 https:/www.nationalgalleries.org/art-and-artists/3237/execution-mary-queen-scots $-1542-1587$ 
of security in the everyday practice of policing as well as within the organization itself.

The fourth and final part of our volume focuses on Mobilities, that is, on the implications that traveling, transfer and the nomadic condition can have for differentiation processes and concomitant security issues. Karina Turmann examines the historical discourse on so-called "tropical diseases" that were widely disseminated in the colonial situation at the end of the $18^{\text {th }}$ century. As she demonstrates, colonialist theories of a 'race'-specific susceptibility to disorders became part of the imperial mindset and, as such, fostered new and competing perceptions of security. In her chapter on contemporary migratory movements between the Unites States and the United Arab Emirates, Shaundel Sanchez investigates how different emigration narratives and practices of religious homecoming interact. Her ethnographic research demonstrates how the illusion of a cohesive Muslim community in the United Arab Emirates helps to preserve and maintain racialized security perceptions of the country of origin. Sanchez' findings link back to the Communities section, as does the chapter of Huub van Baar. His focus is on two types of 'mobile governmentalities'. Firstly, he concentrates on 'nomadization' as a strategy of securitization that keeps people on the move and understands mobility itself as a governing and securitizing strategy. The second form of mobile governmentality that van Baar discusses relates to what William Walters calls "viapolitics", which is a strategy to govern people through administering routes, journeys and vehicles. Van Baar's historical case study is dedicated to Dutch Roma and their racializing treatment in the Netherlands from the beginning of the $20^{\text {th }}$ century onwards. The chapter illustrates once again, and also visually, how the requirements of social normality, in this case a permanent residence, work to identify deviant behavior and social difference and how they trigger securitization processes that seem quite 'normal' and even unproblematic to majorities.

That "security makes a difference" seems a trivial thing to say. The assertion's clumsy but far-reaching ambiguity brings to mind a concept that is at first hardly more dazzling. I am speaking of 'normality'. In the context of security, the ambiguous nature of 'normality' shines through all the different contexts considered and examined in this volume. The most striking impression the contributions assembled here may leave is how 'normality' emerges as a rather threatening precondition to societal life from the point of view of minorities or subaltern people. One may wonder what that says about the historical contexts in question, especially about contexts of 'crisis': Are these potentially perceived as critical and dangerous exactly because 'normality' is suddenly required to allow differentiation 
and to recognise difference? By contrast, the 'routine'-contexts described in the volume tend to speak the language of 'normality rules' in contexts where such normality is happily 'doing difference', thereby creating and enforcing the insecurity of the subaltern? Many questions remain and hopefully give rise to more.

\section{Works Cited}

Bertrand, Sarah (2018): Can the Subaltern Securitize? Postcolonial perspectives on securitization theory and its critics. In: European Journal of International Security 3, 3, pp. 281-299.

Bigo, Didier (2002): Security and Immigration: Toward a Critique of the Governmentality of Unease. In: Alternatives: Global, Local, Political 27, 1, pp. 63-92.

Bigo, Didier/McCluskey, Emma (2018): What is a PARIS Approach to (In)securitization? Political Anthropological Research for International Sociology. In: Gheciu, Alexandra/Wohlforth, William C. (eds.): The Oxford Handbook of International Security (Oxford: Oxford Handbooks Online), DOI: 10.1093/oxfordhb/9780198777854.013.9.

Butler, Judith (2004): Undoing Gender. New York: Routledge.

Buzan, Barry/Wæver, Ole/de Wilde, Jaap (1998): Security. A New Framework for Analysis. Boulder, CO: Lynne Rienner Publishers.

Crenshaw, Kimberlé (1989): Demarginalizing the Intersection of Race and Sex: A Black Feminist Critique of Antidiscrimination Doctrine. In: The University of Chicago Legal Forum, pp. 139-167.

Crenshaw, Kimberlé (1991): Mapping the Margins: Intersectionality, Identity Politics, and Violence against Women of Color. In: Stanford Law Review 43, 6, pp. 1241-1299.

Epstein, Mikhail (2009): Transculture. A Broad Way Between Globalism and Multiculturalism. In: American Journal of Economics and Sociology 68, 1, pp. 327351.

Foucault, Michel (2008): Security, Territory, Population: Lectures at the Collège de France, 1977-1978. New York.

Glissant, Édouard (1990): Poétique de la Relation. Paris: Gallimard

Goldberg, David Theo (2002): The Racial State. Blackwell: Wiley.

Hansen, Lene (2000): The Little Mermaid's Silent Security Dilemma and the Absence of Gender in the Copenhagen School. In: Millennium. Journal of international Studies 29, pp. 285-306.

Hansen, Lene (2020): Are 'core' feminist critiques of securitization theory racist? A reply to Alison Howell and Melanie Richter-Montpetit. In: Security Dialogue 51, 4, pp. 287-304 [https://doi.org/10.1177\%2F0967010620907198]. 
Hirschauer, Stefan/Boll, Tobias (2017): Un/doing Difference. Zur Theorie und Empirie eines Forschungsprogramms. In: Hirschauer, Stefan (ed.): Un/doing Differences. Praktiken der Humandifferenzierung. Weilerswist: Velbrück, pp. 7-26.

Hobson, John M. (2010): The Eurocentric Conception of World Politics: Western International Theory 1760-2010. Cambridge: Cambridge University Press.

Howell, Alison/Richter-Montpetit, Melanie (2019): Racism in Foucauldian Security Studies: Biopolitics, Liberal War, and the Whitewashing of Colonial and Racial Violence. In: International Political Sociology 13, 1, pp. 2-19 [https://doi.org/10. 1093/ips/oly031].

Howell, Alison/ Richter-Montpetit, Melanie (2020): Is securitization theory racist? Civilizationism, methodological whiteness, and antiblack thought in the Copenhagen School. In: Security Dialogue 51, 1, pp. 3-22 [https://doi.org/10 .1177\%2F0967010619862921].

Huysmans, Jef (2006): The Politics of Insecurity. Fear Migration and Asylum in the EU, London: Routledge.

Huysmans, Jef/Dobson, Andrew/Prokhovnik, Raia (eds.) (2006): The Politics of Protection. Sites of Inescurity and Political Agency. London: Routledge.

Julien, François (2016): Il n'y pas d'identité culturelle. Mais nous défendons les ressources culturelles. Paris: L'Herne.

Juneja, Monica (2017): Alternative, Peripheral or Cosmopolitan? Modernism as a Global Process. In: Allerstorfer, Julia/Leisch-Kiesl, Monika (eds.): Global art history (= Linzer Beiträge zur Kunstwissenschaft und Philosophie 8), Bielefeld, pp. 79-107.

Kerner, Ina (2009): Alles intersektional? Zum Verhältnis von Rassismus und Sexismus. In: Feministische Studien 27, 1, pp. 36-50.

Preciado, Paul B. (2020): An Apartment on Uranus. Chronicles of the Crossing, South Pasadena, CA: Semiotext(e).

Said, Edward W. (1978): Orientalism. New York: Routledge.

Schmidt-Linsenhoff, Viktoria (2010): Einleitung. In: Schmidt-Linsenhoff, Viktoria (ed.): Ästhetik der Differenz. Postkoloniale Perspektiven vom 16. bis 20. Jahrhundert. Marburg: Jonas Verlag für Kunst und Literatur, pp. 9-19.

Spivak, Gayatri Chakravorty (1988): Can the Subaltern Speak?. In: Nelson, Cary/ Grossberg, Lawrence (eds.): Marxism and the Interpretation of Culture. Urbana: University of Illinois Press, pp. 271-313.

Spivak, Gayatri Chakravorty (2008). Other Asias. Boston: Wiley-Blackwell 2008.

Spivak, Gayatri Chakravorty (2012): Culture: Situating Feminism. In: Spivak, G.C.: An Aesthetic Education in the Era of Globalization, Cambridge, MA/London, pp. 119-136.

Voelz, Johannes (2017): The Poetics of Insecurity. American Fiction and the Uses of Threat. Cambridge: Cambridge University Press.

Wæver, Ole (1993): Societal Security: the concept. In: Wæver, Ole/Buzan, Barry/Kelstrup, Morten/Lemaitre, Pierre: Identity, Migration and the New Security Agenda in Europe. London, New York: Palgrave Macmillan, pp. 17-58. 
Sigrid Ruby

Wæver, Ole/Buzan, Barry (2020): Racism and Responsibility. The critical limits of deepfake methodology in security studies. A reply to Howell and Richter-Montpetit. In: Security Dialogue 51, 4, pp. 386-394 [https://doi.org/10.1177\%2F09670 10620916153]. 